Original Research Paper

\title{
A Comparative Study on the Reproductive Performance of South African Indigenous Sheep Breeds Following Oestrus Synchronization
}

\author{
1,2 Jabulani Nkululeko Ngcobo, ${ }^{1,2}$ Tshimangadzo Lucky Nedambale, \\ ${ }^{3}$ Tlou Caswell Chokoe and ${ }^{2}$ Fhulufhelo Vincent Ramukhithi

\begin{abstract}
${ }^{1}$ Tshwane University of Technology, Department of Animal Sciences, Private Bag 680, Pretoria, 0001, South Africa ${ }^{2}$ Agricultural Research Council, Germplasm, Conservation, Reproductive and Biotechnologies, Private Bag X2, Irene, 0062, South Africa

${ }^{3}$ Department of Agriculture, Land Reform and Rural Development, Directorate: Farm Animal Genetic Resource, Private Bag X 250, Pretoria, 0001, South Africa
\end{abstract}

\author{
Article history \\ Received: 23-06-2021 \\ Revised: 09-09-2021 \\ Accepted: 22-09-2021 \\ Corresponding Author: \\ Jabulani Nkululeko Ngcobo \\ Tshwane University of \\ Technology, Department of \\ Animal Sciences, Private Bag \\ 680, Pretoria, 0001, South Africa \\ Email: \\ jabulaninkululeko@gmail.com
}

\begin{abstract}
The aim of the study was to compare the effect of age and live body weight on the oestrus response, duration, pregnancy rate and lambing rate among South African indigenous sheep breeds (Zulu sheep $=36$, Bapedi sheep $=26$, Damara sheep $=10$ and Namaqua Afrikaner sheep $=9$ ). Control Intravaginal Drug Release Dispensers (CIDR's) were inserted into the vagina for 10 days. The twitching of tail and standing to be mounted in the presence of the teaser ram were most targeted signs of oestrus. Data were subjected to an appropriate analysis of variance (ANOVA). The scores were subjected to 1:1 Frequency table and a Chi-Square $\left(\chi^{2}\right)$ test for the equal proportions test. One Bapedi ewe loss CIDR before removal date hence was removed from the experimental animals. All Namaqua Afrikaner (100\%) ewes responded to the synchronization protocol with the longest oestrus duration $(70.7 \pm 7.2 \mathrm{~h})$. However, Namaqua Afrikaner sheep scored the lowest rate for conception (44\%) and lambing (44\%). No significant different ( $>>0.05)$ observed for the onset of oestrus among the breeds. Four years old ewes responded better to oestrus synchronization than $\leq 3,5$ and $\geq 6$ years. Nevertheless, ewes that were $\geq 6$ years old had higher conception rate $(94 \%)$ and lambing rate $(84 \%)$. Zulu sheep had higher $(89 \%)$ lambing rate than Damara (60\%) sheep and Namaqua Afrikaner (44\%) sheep. Lighter ewes had higher conception $(83 \%)$ and lambing rate $(90 \%)$ than heavier $(77$ and $64 \%)$ and moderate (68 and $78 \%$ ) weights, respectively. In conclusion, Zulu sheep were more fertile than other South African indigenous breeds following oestrus synchronization. On the other hand, young ewes ( $\leq 3$ years) produced heavier lambs and weaning weight but had higher mortality rate due to inexperience.
\end{abstract}

Keywords: Conservation, Body Weight, Fertility, Indigenous Sheep

\section{Introduction}

Reproductive efficiency is a critical trait but low heritable (Safari et al., 2005) and governed by various factors such as environmental conditions, season, management system and nutrition (McManus et al., 2020). The importance of South African indigenous sheep lies within their ability to reproduce under harsh environmental conditions (Kunene et al., 2009). Namaqua Afrikaner sheep and Damara sheep found in drier areas, characterised by having fat-tails and rumps (Molotsi et al., 2020). Zulu sheep along with Bapedi sheep are Nguni type found in wet areas of eastern coast and characterised as fat-tailed and small body framed size (Kunene and Fossey, 2006; Molotsi et al., 2020; Maqhashu et al., 2020). Various authors such as 
Kunene et al. (2009); Mavule et al. (2013); Hasani et al. (2018) documented a clear role of rearing these breeds in rural farmers where veterinary service and other inputs are lacking (Mavule et al., 2013). Despite the adaptive traits they built, they are however endangered (FAODAD-IS, 2020; Maqhashu et al., 2020) due to indiscriminate crossbreeding to improve growth rate and body weight size (Kunene et al., 2011). Furthermore, uncontrolled mating in rural areas is another factor found to ground genetic erosion of these breeds (Mavule et al., 2016; Selepe et al., 2018) that inhibits adaptive responses to harsh environmental conditions (Bijlsma and Loeschcke, 2012).

Sheep are seasonal breeders and they actively productive during short day light (Carvajal-Serna et al., 2018). Owing to that, assisted reproductive biotechnologies such as oestrus synchronization could be utilised during oestrus and anoestrus seasons to avoid genetic erosion as well to improve their reproductive efficiency (Kasimanickam et al., 2021). Enormous synchronization methods such as progestagengonadrotrophin (Boscos et al., 2002), melatonin and norgestomet implants (Uslu et al., 2012), Control Intravaginal Drug Release (CIDR's) based protocol (Martinez-Ros and Gonzalez-Bulnes, 2019) among many more are being used in small stock production. These oestrus synchronization methods are administered at a short-term (6 - 11 days) and or long-term techniques (12 19 days) (Ramukhithi et al., 2012).

The use of oestrus synchronization in South African indigenous sheep breeds is limited hence continuous breeding is practised and preferred by various farmers (Mavule et al., 2013). This means that South African indigenous sheep lambs and weaned at any time of the year. Therefore, provided the negative effects posed by the climate change, this implies that, lamb mortality will increase in the occasions where climate is unfavourable (Ngcobo et al., 2018). This will thus reduce the number of replacement ewes and rams, sink the selection intensity and complement inbreeding (Selepe et al., 2018). Previous studies in these breeds focused merely on the genetic makeup (Selepe et al., 2018), genetic diversity and population structure (Qwabe et al., 2013; Maqhashu et al., 2020), utilization (Kunene et al., 2011), morphological differentiation (Mavule et al., 2016) and implications for conservations (Soma et al., 2012). However, very little has been done on their reproductive performance. Therefore, the aim of this study was to evaluate the effect of breed, age and body weight on the oestrus response, duration, pregnancy rate and lambing rate of South African indigenous sheep breeds.

\section{Materials and Methods}

\section{Ethical Approval and Study Site}

The Agricultural Research Council (APAEC 2019/23) and Tshwane University of Technology animal research ethics committee (AREC2020/05/001) approved the study procedures. The study site was the Agricultural Research Council (ARC), Irene, South Africa. The ARC, Irene area is situated in the Highveld, $1525 \mathrm{~m}$ above sea level. This area extends between 25 53'59.6' South latitude and 28 12 '51.6' East longitudes (Grobbelaar et al., 2010).

\section{Experimental Animals and Design}

Only Eight-one South African indigenous ewes (Zulu sheep $=36$, Bapedi sheep $=26$, Damara sheep $=$ 10 and Namaqua Afrikaner sheep =9) are left at the ARC, Irene and were all used in this study. However, 1 Bapedi ewe loss CIDR device before removal (10 ${ }^{\text {th }}$ day) and was removed from the study hence the final total number of ewes used in this study was 80 . The ewes were allocated or subdivided based on breed and age ( $\leq 3$ years, 4 years, 5 years and $\geq 6$ years) with their body weight classified as light $(45.4 \pm 5.6 \mathrm{~kg})$, moderate $(53.6 \pm 4.2 \mathrm{~kg})$ and heavy $(77.4 \pm 6.8 \mathrm{~kg})($ mean $\pm \mathrm{SD})$ as described by Mpofu et al. (2021, unpublished). All experimental animals were born and reared at the Agricultural Research Council (ARC), Irene. Experimental animals were grazing on Kikuyu grass and supplemented with pellets during winter season and water provided ad-libitum throughout the study. Pellets supplemented contains crude protein 130, moisture 120.54 , crude fat 25 , crude fibre 120 , calcium 6 , phosphorus 2, potassium 9.60, magnesium 2.30, selenium 0.18 , manganese 36.00 , iron 67.0 , zinc 60.0 , copper 13.0 , iodine 0.28 , urea 0 , ca:p ratio $1.4: 1(\mathrm{~g} / \mathrm{kg})$.

\section{Oestrus Synchronization}

A short-term oestrus synchronization protocol as described by Ramukhithi et al., (2012) was used with few amendments. In brief, Controlled Intravaginal Drug Release dispensers (CIDR) (Zoetis, CIDR ${ }^{\circledR}$ ), containing $0.3 \mathrm{~g}$ progesterone was inserted according to the manufacturer's instructions, using disinfected applicator. At the CIDR's removal ( $10^{\text {th }}$ day), ewes were injected intramuscularly with $2.5 \mathrm{~mL}$ of Pregnant Mare Serum Gonadotrophin (PMSG), (Intervet®) to stimulate ovulation (Lehloenya et al., 2005). Total of 5 teaser rams were used, with each teaser ram given at least $5 \mathrm{~min}$ and rested thereafter.

\section{Onset and Duration of Oestrus}

Following CIDR withdrawal, ewes were observed for the onset and duration of oestrus for $72 \mathrm{~h}$, at an 
interval of $12 \mathrm{~h}(6 \mathrm{~h} 00$ am and $18 \mathrm{~h} 00 \mathrm{pm})$ using teaser ram. Among other various signs of oestrus, the twitching of tail and standing to be mounted (Lehloenya et al., 2005; Ramukhithi et al., 2012; Gore and Lehloenya, 2020) were targeted.

\section{Hand Mating and Pregnancy Diagnosis}

Ewes showing signs of oestrus were mated using fertility-tested rams following inception of oestrus signs. Sixteen breeding rams (Zulu sheep $=7$, Bapedi sheep $=5$, Namaqua Afrikaner sheep $=2$ and Damara sheep $=2$ ) and mating took place at a ratio of 1:5. Each ram was allocated $10 \mathrm{~min}$ to mount any ewe of respective breed in the pool of five ewes at a time (1:5). Nevertheless, once an ewe was mounted it was then removed so that it does not temper with the breeding ram in mounting other ewes and to limit mounting one ewe more than once. Ewes that did not show any signs of oestrus were left with rams for 5 days. Forty-five days following mating, pregnancy diagnosis was conducted using ultrasound scanner (Ibex pro, USA) connected to the abdominal probe $47-63 \mathrm{~Hz}$ linear array probe (E.L medical probe, 252420, USA). For the ewes, which did not show any signs of oestrus and confirmed pregnant after 45 days were recorded as silent heaters.

\section{Statistical Analysis}

The data was subjected to an appropriate Analysis of Variance (ANOVA) in SAS, 1999). The ShapiroWilk's test was performed on the standardized residuals to test for deviations from normality (Shapiro and Wilk, 1965). In cases where significant deviation from normality was observed and due to skewness, outliers were removed until it was normal or symmetrically distributed. Student's t-LSDs (Least significant differences) were calculated at a 5\% significance level to compare means of significant source effects (Snedecor and Cochran, 1967). The scores were subjected to 1:1 Frequency table and a ChiSquare $\left(\chi^{2}\right)$ test was performed to test for equal proportions. Contingency $\mathrm{R}$ x $\mathrm{C}$ frequency tables were performed for association between treatments (Snedecor and Cochran, 1967). The tests were performed for association (Patterns) and where significant differences were found graphs were constructed to demonstrate the difference in patterns. Correlation co-efficiency among parameters was performed using Pearson's correlation coefficient. The above analysis was performed using SAS version 9.4 statistical software (SAS, 1999).

\section{Results}

This study evaluated the effect of breed on the oestrus response, onset, duration, conception and lambing rate and the results are obtainable in Table 1. One Bapedi ewe loss CIDR and was removed from the experimental animals. There was a significant $(\mathrm{P}<0.05)$ breed variations for oestrus response among the South African indigenous breeds used. However, there were silent heaters in all breeds but more in Zulu sheep (data not shown). Noteworthy, all Namaqua Afrikaner (100\%) ewes responded to oestrus synchronization followed by Bapedi $(88 \%)$ ewes and Zulu (83\%) ewes, whereas Damara ewes scored the lowest $(70 \%)$.

No significant different $(\mathrm{P}>0.05)$ observed among breeds (Zulu sheep, Bapedi sheep and Namaqua Afrikaner sheep) for the onset of oestrus. Noteworthy, Namaqua Afrikaner ewes took longer period $(69.7 \pm 10.1 \mathrm{~h})$ of time showing signs of oestrus, whereas, Damara sheep had a shorter period $(27 \pm 11.7 \mathrm{~h})$ of time showing signs of oestrus in comparison to other breeds.

Conception rate was higher $(86 \%)$ in Zulu sheep and Bapedi (84\%) sheep as compared to that of Damara (70\%) sheep and Namaqua Afrikaner (44\%) sheep. Zulu (89\%) sheep and Bapedi (88\%) sheep had higher lambing rate than Damara (60\%) sheep and Namaqua Afrikaner (44\%) sheep.

The effect of age and body weight on the oestrus response, onset, duration, conception and lambing rate were further evaluated and the results are attainable in Table 1. Four years old ewes were associated with the higher $(93 \%)$ oestrus response than $\leq 3(83 \%), 5(83 \%)$ and $\geq 6(83 \%)$ years. However, ewes that were $\geq 6$ years had high conception rate $(94 \%)$ than $\leq 3$ years $(63 \%), 4$ years $(79 \%)$ and 5 years $(83 \%)$ old. Lambing rate was also higher $(84 \%)$ in the $\geq 6$ years old ewes than $\leq 3$ years $(75 \%), 4$ years $(79 \%)$ and $5(79 \%)$ years old.

Moderate weighing ewes responded better (89\%) to oestrus synchronization than heavier $(86 \%)$ and lighter ewes $(83 \%)$. Nonetheless, there was no significant difference $(\mathrm{P}<0.05)$ on the onset and the duration of oestrus when lighter, moderate and heavier ewes were compared.

Lighter ewes had higher conception rate $(83 \%)$ and lambing (90\%) rate than heavier (77 and 64\%) and moderate (68 and 78\%), respectively. Ewes that were 4 years old had better oestrus response rate $(93 \%)$ than 3 years ewes $(83 \%), 5$ years ewes $(83 \%)$ and $>6$ years ewes $(83 \%)$. However, no significant difference observed among age groups $(<3,4,5,>6$ years $)$ for the onset of oestrus.

The effect of body weight on the oestrous response, onset, duration conception and lambing rate within the breeds are obtainable in Table 2. All lighter Namaqua Afrikaner ewes (100\%) responded to oestrus synchronization, followed by lighter Bapedi (93\%) sheep, lighter Damara (80\%) sheep, whereas lighter Zulu ewes 
scored the lowest $(70 \%)$. All moderate Bapedi sheep and Namaqua Afrikaner (100\%) ewes responded to oestrus synchronization, followed by moderate Zulu (89\%) sheep and moderate Damaras' (60\%) sheep. All heavy Zulu sheep and Namaqua Afrikaner (100\%) sheep responded to oestrus synchronization. However, body weight classifications within the breeds could not lead to any significant difference $(p<0.05)$ for the onset of oestrus. However, lightweight Namaqua Afrikaner sheep had a longest oestrus duration $(81 \pm 14.6 \mathrm{~h})$ whereas, light Damara ewes scored the lowest oestrus duration $(45 \pm 14.6 \mathrm{~h})$.

Moderate weight Damara ewes had higher conception rate $(80 \%)$ and lambing rate $(80 \%)$. Lighter Zulu ewes scored $94 \%$ for both conception and lambing rate, whereas heavier Zulu ewes scored $90 \%$ for both conception and the lambing rate. Lighter Bapedi ewes had $86 \%$ conception and $100 \%$ lambing rate.

Conception rate was higher in the moderate weighing Damaras (80\%) sheep followed by Zulu sheep and Bapedi sheep (both at 67\%), whereas moderate weighing Namaqua Afrikaner sheep scored the lowest (50\%). Heavy Zulu ewes had high conception rate $(90 \%)$ than Bapedi $(86 \%)$ sheep and Namaqua Afrikaner (33\%) sheep. Higher (100\%) lambing rate was observed on lighter Bapedi sheep followed by lighter Zulu sheep (94\%). Lambing rate was higher in heavy Zulu ewes (90\%) than Bapedi (63\%) sheep and Namaqua Afrikaner (0\%) sheep. No heavy Damara ewes were found at the Agricultural Research Council.

The results on the effect of breed and age on the litter size are obtainable in Table 3. Single born lambs were dominating in Bapedi (68\%) sheep. However, twin (53\%) and quadruplets (3\%) were dominating in Zulu sheep. No significant $(\mathrm{P}<0.05)$ difference observed between Zulu (3\%) sheep and Namaqua Afrikaner (11\%) sheep in terms of triplets birth. Ewes that are $\leq 3$ years had higher single born lambs $(63 \%)$ compared to those with 4,5 and $>6$ years, 32 , 30 and $50 \%$, respectively. Twins born lambs were higher
(56\%) on the ewes that are 5 years old followed by $\geq 6$ years (44\%). Only one ewe from $\geq 3$ years and 4 years group gave birth to triplets, whereas only one ewe from 4 years old group gave birth to quadruplets.

Results about the influence of breed and age on lambs' birth weight, weaning weight and mortality rate are obtainable in Table 4 . There was a significant $(\mathrm{P}<0.05)$ variations among the breeds on birth weight. Damara lambs were heavier $(3.9 \pm 0.2 \mathrm{~kg})$ than other breeds. No significant different $(\mathrm{P}>0.05)$ observed among Zulu sheep, Bapedi sheep and Namaqua Afrikaner lambs on birth weight, with similar trend for weaning weight. Zulu sheep were associated with low weaning weight because of higher litter size than other breeds. There was a higher mortality rate (67\%) in Damara sheep breed than Zulu (31\%) sheep and Namaqua Afrikaner (44\%) sheep with Bapedi sheep scoring the lowest lamb mortality rate $29 \%$ ). These results suggest a poor mothering ability in Damara sheep.

Ewes that were $\leq 3$ years old had higher lamb birth weight $(3.5 \pm 0.2 \mathrm{~kg})$ than 4 years old ewes $(2.7 \pm 0.2 \mathrm{~kg})$. Five and $\geq 6$ years old ewes had lambs that had same birth weight $(\mathrm{P}>0.05)$. Three years old ewes further yielded higher weaning weight $(13.5 \pm 0.8 \mathrm{~kg})$ than 6 years ewes $(11.8 \pm 0.7$ $\mathrm{kg}$ ), though could not differ significantly with the 4 years $(12.4 \pm 0.9 \mathrm{~kg})$ and 5 years $(12.4 \pm 0.6 \mathrm{~kg})$. Three years and below old ewes had high $(50 \%)$ mortality rate than 5 years $(25 \%)$ and $\geq 6$ years $(27 \%)$ whereas, 4 years old ewes had significant low (20\%) mortality rate. Most lamb mortality causes were lamb negligence/starvation that might be due to various reason such as inexperience in young ewes.

The correlation coefficient between Lamb Weaning Weight (LWW), Lamb Birth Weight (LBW), Dam Weight at Mating (DWM) and Dam Weight at Lambing (DWL) are obtainable in Table 5. There was a positive correlation between LBW and LWW ( $r=0.67$, p<0.0001). However, although heavier lambs at birth are likely to have heavy weaning weight, it is not recommended due to possible lambing difficulties that were observed in Bapedi sheep and Damara ewes (data not shown).

Table 1: Effect of breed, age and body weight on oestrous response, onset, duration and conception rate following oestrus synchronization of South African indigenous sheep

\begin{tabular}{|c|c|c|c|c|c|}
\hline Sheep breeds & $\begin{array}{l}\text { Oestrus response } \\
(\%)\end{array}$ & $\begin{array}{l}\text { Onset of oestrus } \\
\text { (h) (mean } \pm \text { SE) }\end{array}$ & $\begin{array}{l}\text { Oestrous duration } \\
\text { (h) }(\text { mean } \pm \mathrm{SE})\end{array}$ & Conception rate $(\%)$ & Lambing rate $(\%)$ \\
\hline Zulu & $83(30 / 36)^{\mathrm{c}}$ & $33.3 \pm 3.1^{\mathrm{a}}$ & $52 \pm 5.1^{\mathrm{ab}}$ & $86(31 / 36)^{\mathrm{a}}$ & $89(32 / 36)^{\mathrm{a}}$ \\
\hline Bapedi & $88(22 / 25)^{\mathrm{b}}$ & $31.9 \pm 4.3^{\mathrm{a}}$ & $56.6 \pm 7.1^{\mathrm{b}}$ & $84(21 / 25)^{\mathrm{a}}$ & $88(22 / 25)^{\mathrm{a}}$ \\
\hline Namaqua Afrikaner & $100(9 / 9)^{\mathrm{a}}$ & $39 \pm 6.1^{\mathrm{a}}$ & $69.7 \pm 10.1^{\mathrm{a}}$ & $44(4 / 9)^{\mathrm{c}}$ & $44(4 / 9)^{\mathrm{c}}$ \\
\hline Damara & $70(7 / 10)^{d}$ & $23 \pm 7.1^{b}$ & $27 \pm 11.7^{\mathrm{c}}$ & $70(7 / 10)^{\mathrm{b}}$ & $60(6 / 10)^{b}$ \\
\hline \multicolumn{6}{|l|}{ Age (years) } \\
\hline$\leq 3$ years & $83(20 / 24)^{b}$ & $37.5 \pm 3.6$ & $51.5 \pm 5.9$ & $63(15 / 24)^{\mathrm{c}}$ & $75(18 / 24)^{\mathrm{c}}$ \\
\hline 4 years & $9313 / 14)^{\mathrm{a}}$ & $33.4 \pm 4.6$ & $58.3 \pm 8.7$ & $79(11 / 14)^{\mathrm{b}}$ & $79(11 / 14)^{\mathrm{b}}$ \\
\hline 5 years & $83(20 / 24)^{b}$ & $31 \pm 3.5$ & $51 \pm 6.4$ & $83(20 / 24)^{b}$ & $79(19 / 24)^{b}$ \\
\hline$\geq 6$ years & $83(15 / 18)^{b}$ & $30.7 \pm 4.1$ & $47.3 \pm 7.2$ & $94(17 / 18)^{\mathrm{a}}$ & $84(16 / 18)^{a}$ \\
\hline \multicolumn{6}{|l|}{ Body weight classification } \\
\hline Light & $83(33 / 40)^{\mathrm{c}}$ & $33.9 \pm 3.3$ & $39 \pm 9.1^{\mathrm{b}}$ & $83(33 / 40)^{\mathrm{a}}$ & $90(36 / 40)^{\mathrm{a}}$ \\
\hline Moderate & $89(16 / 18)^{\mathrm{a}}$ & $32.9 \pm 4.8$ & $61.6 \pm 7.9^{\mathrm{a}}$ & $68(13 / 18)^{\mathrm{c}}$ & $78(14 / 18)^{b}$ \\
\hline Heavier & $86(19 / 22)^{\mathrm{b}}$ & $28.7 \pm 7$ & $39 \pm 11.7^{b}$ & $77(17 / 22)^{\mathrm{b}}$ & $64(14 / 22)^{c}$ \\
\hline
\end{tabular}

Values with different superscripts within the same column and on the cell differ significantly $(\mathrm{P}<0.05)$ 
Table 2: Interaction between South African indigenous sheep breeds and body weight classification and their effect of body weight on oestrous response, onset duration and conception rate

\begin{tabular}{|c|c|c|c|c|c|}
\hline \multirow[b]{2}{*}{$\begin{array}{l}\text { Breed x BW } \\
\text { classification }\end{array}$} & \multicolumn{5}{|l|}{ Measurable parameters } \\
\hline & Oestrus response $(\%)$ & $\begin{array}{l}\text { Onset of oestrus } \\
\text { (h) (Mean } \pm \text { SE) }\end{array}$ & $\begin{array}{l}\text { Oestrous duration } \\
\text { (h) }(\text { Mean } \pm \text { SE) }\end{array}$ & Conception rate $\%$ & Lambing rate $\%$ \\
\hline \multicolumn{6}{|l|}{ Light weight } \\
\hline Zulu & $70(12 / 17)$ & $29.7 \pm 4.3^{\mathrm{b}}$ & $38.1 \pm 7.1^{\mathrm{c}}$ & $94(16 / 17)$ & $94(16 / 17)$ \\
\hline Bapedi & $93(13 / 14)$ & $36.9 \pm 4.7^{\mathrm{a}}$ & $58.3 \pm 7.8^{\mathrm{b}}$ & $86(12 / 14)$ & $100(14 / 14)$ \\
\hline Namaqua Afrikaner & $100(4 / 4)$ & $33 \pm 8.8^{\mathrm{ab}}$ & $81 \pm 14.6^{\mathrm{a}}$ & $50(2 / 4)$ & $50(2 / 4)$ \\
\hline Damara & $80(4 / 5)$ & $36 \pm 7.8^{\mathrm{a}}$ & $36 \pm 13.1^{\mathrm{c}}$ & $60(3 / 5)$ & $80(4 / 5)$ \\
\hline \multicolumn{6}{|l|}{ Moderate weight } \\
\hline Zulu & $89(8 / 9)$ & $30.7 \pm 5.8$ & $61.3 \pm 9.8^{\mathrm{a}}$ & $67(6 / 9)$ & $78(7 / 9)$ \\
\hline Bapedi & $100(3 / 3)$ & $32 \pm 10.1$ & $68 \pm 16.9^{a}$ & $67(2 / 3)$ & $100(3 / 3)$ \\
\hline Namaqua Afrikaner & $100(2 / 2)$ & $36 \pm 12.4$ & $72 \pm 20.7^{\mathrm{a}}$ & $50(1 / 2)$ & $100(2 / 2)$ \\
\hline Damara & $60(3 / 5)$ & $33 \pm 8.8$ & $45 \pm 14.6^{\mathrm{b}}$ & $80(4 / 5)$ & $80(4 / 5)$ \\
\hline \multicolumn{6}{|l|}{ Heavy weight } \\
\hline Zulu & $100(10 / 10)$ & $39.6 \pm 5.5^{\mathrm{a}}$ & $56.4 \pm 9.3^{\mathrm{a}}$ & $90(9 / 10)$ & $90(9 / 10)$ \\
\hline Bapedi & $75(6 / 8)$ & $27 \pm 6.2^{\mathrm{b}}$ & $43.5 \pm 10.3^{\mathrm{b}}$ & $86(7 / 8)$ & $63(5 / 8)$ \\
\hline Namaqua Afrikaner & $100(3 / 3)$ & $48 \pm 10.1^{\mathrm{a}}$ & $56 \pm 16.9^{a}$ & $33(1 / 3)$ & $0(0 / 3)$ \\
\hline Damara & - & - & - & - & - \\
\hline
\end{tabular}

Value with different superscripts within the same column on the same cell differ significantly $(\mathrm{P}<0.05)$

Table 3: The effect of breed and age on the litter size of South African indigenous sheep following oestrus synchronization

\begin{tabular}{lllll}
\hline Breed & Single $\%$ & Twins $\%$ & Triplets \% & Quadruplets $\%$ \\
\hline Zulu & $28(10 / 36)^{\mathrm{d}}$ & $53(19 / 36)^{\mathrm{a}}$ & $3(1 / 36)^{\mathrm{a}}$ & $3(1 / 36)^{\mathrm{a}}$ \\
Bapedi & $68(17 / 25)^{\mathrm{a}}$ & $28(7 / 25)^{\mathrm{b}}$ & $0(0 / 25)$ & $0(0 / 25)$ \\
Namaqua Afrikaner & $33(3 / 9)^{\mathrm{c}}$ & $11(1 / 9)^{\mathrm{c}}$ & $11(1 / 9)^{\mathrm{a}}$ & $0(0 / 9)$ \\
Damara & $50(5 / 10)^{\mathrm{b}}$ & $20(2 / 10)^{\mathrm{b}}$ & $0(0 / 10)$ & $0(0 / 10)$ \\
Age (years) & & & \\
$\leq 3$ & $63(15 / 24)^{\mathrm{a}}$ & $17(4 / 24)^{\mathrm{d}}$ & $4(1 / 24)^{\mathrm{a}}$ & $0(0 / 24)$ \\
4 & $33(5 / 15)^{\mathrm{c}}$ & $27(4 / 15)^{\mathrm{c}}$ & $7(1 / 15)^{\mathrm{a}}$ & $7(1 / 15)^{\mathrm{a}}$ \\
5 & $32(8 / 25)^{\mathrm{c}}$ & $56(14 / 25)^{\mathrm{a}}$ & $0(0 / 25)$ & $0(0 / 25)$ \\
$\geq 6$ & $50(8 / 16)^{\mathrm{b}}$ & $44(7 / 16)^{\mathrm{b}}$ & $0(0 / 16)$ & $0(0 / 16)$ \\
\hline
\end{tabular}

Values with different superscripts within the same column on the same cell differ significantly $(\mathrm{P}<0.05)$

Table 4: The effect of breed and age on lambs' birth, weaning weight and mortality rate of South African indigenous sheep following oestrus synchronization

\begin{tabular}{llll}
\hline Breed & Lamb birth weight $(\mathrm{kg})($ Mean \pm SE) & Lamb weaning weight $(\mathrm{kg})($ Mean \pm SE) & Mortality rate $(\%)$ \\
\hline Zulu & $2.8 \pm 0.1^{\mathrm{b}}$ & $11.6 \pm 0.5^{\mathrm{ba}}$ & $31(17 / 55)^{\mathrm{c}}$ \\
Bapedi & $3.1 \pm 0.1^{\mathrm{b}}$ & $13.4 \pm 0.7^{\mathrm{ba}}$ & $29(9 / 31)^{\mathrm{c}}$ \\
Namaqua Afrikaner & $3.1 \pm 0.2^{\mathrm{b}}$ & $10.5 \pm 0.8^{\mathrm{b}}$ & $44(4 / 9)^{\mathrm{b}}$ \\
Damara & $3.9 \pm 0.2^{\mathrm{a}}$ & $14.1 \pm 1.2^{\mathrm{a}}$ & $67(6 / 9)^{\mathrm{a}}$ \\
Age (years) & & & \\
$\leq 3$ & $3.8 \pm 0.2^{\mathrm{a}}$ & $13.5 \pm 0.8^{\mathrm{a}}$ & $50(13 / 26)^{\mathrm{a}}$ \\
4 & $2.7 \pm 0.2^{\text {ba }}$ & $12.4 \pm 0.9^{\mathrm{ba}}$ & $20(4 / 20)^{\mathrm{d}}$ \\
5 & $2.7 \pm 0.1^{\mathrm{ba}}$ & $12.4 \pm 0.6^{\mathrm{ba}}$ & $25(9 / 36)^{\mathrm{c}}$ \\
$\geq 6$ & $3 \pm 0.2^{\mathrm{b}}$ & $11.8 \pm 0.7^{\mathrm{b}}$ & $27(6 / 22)^{\mathrm{b}}$ \\
\hline
\end{tabular}

Values with different superscripts within the same column on the same cell differ significantly $(\mathrm{P}<0.05)$

Table 5: Pearson's correlation among LWW, LBW, DW at weaning and at mating as the Birth weight

\begin{tabular}{lll}
\hline Parameters & DWM & LBW \\
\hline LBW & $0.44 * *$ & \\
LWW & $0.39 *$ & $0.67 * *$
\end{tabular}

DWM - dam weight at mating, LBW - lamb birth weight, LWW - lamb weaning weight

$* * \mathrm{p}<0.0001, * \mathrm{p}<0.001$

\section{Discussion}

This study evaluated the effect of breeds on the oestrus onset, response, duration, conception and lambing rate. Oestrus synchronization is a vital tool for successful and the control of reproduction efficiency, particularly conservation through population improvement (Gibbons et al., 2019). It has been found that, oestrus 
response ranges from 4.3 - $100 \%$ although, highly depending on the protocol employed (Omontese et al., 2016). There was a huge breed variation observed in this study in most of the parameters measured. These results were like that of Gizaw et al. (2016), who reported a noticeable variation among different breeds following oestrus synchronization. However, not comparable to that reported by Mekuriaw et al. (2016) in the Menz and crossbred sheep. Nevertheless, all South African indigenous breeds responses to oestrus synchronization fell within a range reported by Omontese et al. (2016). Moreover, environmental condition and season also does influence oestrous responses (Mukasa-Mugerwa et al., 2002).

This study could not find any significant differences for the onset of oestrus. These results were however, different to that observed by Kridli et al. (2009), in brown and black faced Awassi ewes. Nonetheless, it appears that the onset of oestrus following oestrus synchronization occasionally depends on the protocol used (Uriol et al., 2019). However, the Namaqua Afrikaner ewes took longer period showing signs of oestrus. This could be beneficial to farmers who prefers to do double insemination (Paulenz et al., 2003). According to Ramukhithi et al. (2012), short period on oestrus might have undesirable effect on conception rate if artificial insemination was to be conducted at the recommended 52 $h$ following CIDR's removal.

There was a breed variation for conception rate, with Zulu and Bapedi performing better than that of Namaqua Afrikaner and Damara. Results found between Bapedi sheep and Zulu sheep were similar to that reported previously by Kridli et al. (2009); Zeleke et al. (2005) and Mansur et al. (2018) where lambing rate could not differ among breeds and their lactation statuses. The conception and lambing rate of Zulu sheep and Bapedi sheep were comparable to Farrag (2019) results who reported that, oestrus synchronization result in higher conception rate on the Abou-Delik sheep.

Age and body weight were also among numerous factors affected oestrus response, conception rate and the lambing rate. Similar effect of age was reported in Central Anatolian Merino sheep (Aktas et al., 2015) and in Juvenile ewes (Edwards et al., 2016). Nevertheless, our results differed from that reported by Al-Sharify and Altaei (2020) who found younger ewes to perform better than older ewes in local Awassi and Iranian Karakul sheep in terms oestrus responses. Nevertheless, these differences might be because of the age groups comparison in these two studies. In terms of body weight as a factor influencing measured parameters, our observation however differed to that reported by Gizaw et al. (2016), who found the heavier ewes to respond better to oestrus synchronization compared to lighter ewes. In their study, it was indicated that, there would be $14.7 \%$ chances of oestrous response rate to increase when body weight is increased. This was also supported by Mbayahaga et al. (1998) in the local Burundian ewes.

Zulu sheep were mostly lighter and had more silent heaters however, with higher conception rate. These results differed to those of Aktas et al. (2015) in Anatolian Merino sheep where it they concluded that heavier ewes conceive and lambs better than lighter ewes. Season of the year (Mukasa-Mugerwa et al., 2002) and nutritive quality has adverse effect on animal productivity (Robertson and Friend, 2019). Therefore, these equivocal results might be due to the quality of pastures in these two studies as they were conducted in different seasons (Hashemi et al., 2006). Despite that differences, our results looked better than that reported by Maqhashu (2020), where only $81 \%$ Bapedi ewes responded to oestrus synchronization. These transformations might be due to the age and the different environment with different temperatures in their study and the current study. Heavier ewes were associated with higher oestrus responses, these results were in line to those reported by Maqhashu (2020).

Current study observed high breed and age variation for litter size, with Bapedi sheep associated with the single born lambs. Litter size variations among the breeds has been reported previously (Kandiwa et al., 2020) and can have an influence on the birth weight (Assan, 2013a). Low birth weight in multiple birth is solely due to the shortage of feed supply in the uterus (Assan, 2013b). Moreover, breed, parity, sex and type of birth and the season were reported to affect birth weight and weaning weight (Baneh and Hafezian, 2009; Bermejo et al., 2010; Petrovic et al., 2011; Oyebade et al., 2012). For instance, single born lambs are heavier and grow faster than twins, triplets and quadruplets (Petrovic et al., 2011) because there is no milk competition when they are feeding from their mothers (Bermejo et al., 2010). Selecting for heavier lambs might increase body weight development and growth rate (Ata and Hamad, 2015) thus increasing farm per capita. Nevertheless, birth weight is highly correlated to lambing difficulties such as dystocia (Assan, 2013a). In the current study no lambing difficulties were associated with the litter size (data not shown).

Ewes that were $\leq 3$ years old had higher lamb birth weight than 4 years old ewes. Five and $\geq 6$ years old ewes had lambs with the same birth weight. These results contradict to Kenyon et al. (2004) and Petrovic et al. (2011) when Hoggets and Serbian indigenous sheep were used, respectively. These differences might due to different body size as indigenous Serbian sheep are larger framed breed as compare to South African indigenous sheep. Moreover, age of the ewe is another essential factor determining fertility (Aktas et al., 2015; Gibbons et al., 2019). 
The study further examined the correlation between LWW, LBW, DWM and DWL. Positive correlation found between LBW and LWW was in line to with that of Assan and Makuza, (2005) on the indigenous Sabi, Mutton Merino and Dorper sheep. Besides that, weaning weight is an important economic trait influential to the profit returns in sheep production (Assan and Makuza, 2005).

\section{Conclusion}

Namaqua Afrikaner sheep responded well to oestrus synchronization and took longer period showing signs of oestrus. However, Zulu sheep and Bapedi sheep were more fertile than other Damara sheep and Namaqua Afrikaner sheep following oestrus synchronization. Age does influence South African indigenous sheep oestrus response, conception rate and lambing rate. Young ewes $(\leq 3$ years) produced heavier lambs but their lambs' mortality rate was higher due to inexperience. However, older ewes (5 and $\geq 6$ had higher conception and lambing rate.

\section{Author's Contributions}

Jabulani Nkululeko Ngcobo: Designed, collected data and wrote the article.

Fhulufhelo Vincent Ramukhithi: Designed, collected, wrote, reviewed and edited the article.

Tlou Caswell. Chokoe: Reviewed and edited the article.

Tshimangadzo Lucky Nedambale: Wrote and edited the article.

\section{Funding}

Department of Agriculture, Land Reform and Rural Development (DALRRD), Tshwane University of Technology, AgriSeta and National Research FoundationDeutscher Akademischer Austauschdienst German Academic Exchange service (NRF-DAAD) scholarship.

\section{Ethics}

All authors declare no conflict of interest in this study. Moreover, the corresponding author declare that this study is the original work containing unpublished material. All authors as appear read and approved the final version of this study.

\section{References}

Aktaş, A. H., Dursun, Ş., Doğan, Ş., Kiyma, Z., Demirci, U., \& Halıc1, I. (2015). Effects of ewe live weight and age on reproductive performance, lamb growth and survival in Central Anatolian Merino sheep. Archives Animal Breeding, 58(2), 451-459.

https://aab.copernicus.org/articles/58/451/2015/
Al Mansur, M. A., Alam, M. G. S., Jha, P. K., Rimon, M. A., Naher, N., \& Bari, F. Y. (2018). Conception rate following intra-cervical artificial insemination using frozen semen at field level in indigenous sheep of Bangladesh. Asian Journal of Medical and Biological Research, 4(1), 55-62.

https://www.banglajol.info/index.php/AJMBR/art icle/view/36822

Al-Sharify, M. A. H., \& Altaei, H. M. A. (2020). Factors affecting prolificacy and fertility traits for local awassi sheep and iranian karakul and their crosses. Plant Archives, 20(2), 4126-4130.

http://www.plantarchives.org/SPL\%20ISSUE\%202 0-2/677_4126-4130_.pdf

Assan, N. (2013a). Opportunities and Challenges in Use of Imported Livestock than Utilization of Local Animal Genetic Resources in Zimbabwe: a Review. Journal of Animal Production Advances, 3(4), 97-106.

Assan, N. (2013b). Various factors influencing birth weight in animal production. Scientific Journal of Review, 2(7), 156-175.

http://citeseerx.ist.psu.edu/viewdoc/download?doi=1 0.1.1.367.8957\&rep=rep1\&type=pdf

Assan, N., \& Makuza, S. M. (2005). The effect of nongenetic factors on birth weight and weaning weight in three sheep breeds of Zimbabwe. Asian-australasian journal of animal sciences, 18(2), 151-157. https://www.animbiosci.org/journal/view.php?doi=1 0.5713/ajas.2005.151

Ata, M., \& Hamad, H. (2015). Relationship between birth weight and body growth of Awassi lambs during early weaning. Journal of Biology, Agriculture and Healthcare, 3, 5-9.

https://citeseerx.ist.psu.edu/viewdoc/download?doi= 10.1.1.735.7455\&rep=rep $1 \&$ type $=$ pdf

Baneh, H., \& Hafezian, S. H. (2009). Effects of environmental factors on growth traits in Ghezel sheep. African Journal of Biotechnology, 8(12). https://www.ajol.info/index.php/ajb/article/view/60943

Bermejo, L. A., Mellado, M., Camacho, A., Mata, J., Arévalo, J. R., \& De Nascimento, L. (2010). Factors influencing birth and weaning weight in Canarian hair lambs. Journal of Applied Animal Research, 37(2), 273-275.

https://www.tandfonline.com/doi/abs/10.1080/0971 2119.2010.9707140

Bijlsma, R., \& Loeschcke, V. (2012). Genetic erosion impedes adaptive responses to stressful environments. Evolutionary Applications, 5(2), 117-129. https://onlinelibrary.wiley.com/doi/full/10.1111/j.17 52-4571.2011.00214.x

Boscos, C. M., Samartzi, F. C., Dellis, S., Rogge, A., Stefanakis, A., \& Krambovitis, E. (2002). Use of progestagen-gonadotrophin treatments in oestrus synchronization of sheep. Theriogenology, 58(7), 1261-1272.

https://www.sciencedirect.com/science/article/abs/pi i/S0093691X02010403 
Carvajal-Serna, M., Cardozo, J. A., Grajales-Lombana, H., Cebrian-Perez, J. A., \& Muino-Blanco, T. (2018). Sperm quality and seminal plasma proteins in three sheep breeds under high altitude and tropical conditions (No. ART-2018-107590).

https://zaguan.unizar.es/record/75054

Edwards, S. J., Smaill, B., O’Connell, A. R., Johnstone, P. D., Stevens, D. R., Quirke, L. D., ... \& Juengel, J. L. (2016). Reduced ovulation rate, failure to be mated and fertilization failure/embryo loss are the underlying causes of poor reproductive performance in juvenile ewes. Animal reproduction science, 167, 125-132. https:/www.sciencedirect.com/science/article/abs/pi i/S0378432016300574

FAO-DAD-IS, (2020). www.fao.org/dad-is/en

Farrag, B. (2019). Productive Characteristics and Reproductive Responses to Oestrus Synchronization and Flushing in Abou-Delik Ewes Grazing in Arid Rangelands in Halaieb-Shalateen-Abouramad Triangle of Egypt. World's Veterinary Journal, 9(3), 201-210.

Gibbons, A. E., Fernandez, J., Bruno-Galarraga, M. M., Spinelli, M. V., \& Cueto, M. I. (2019). Technical recommendations for artificial insemination in sheep. Animal reproduction, 16, 803-809.

https://www.scielo.br/j/ar/a/KWqh5SnNNqLGqPc9 Dt9RSxp/?lang=en

Gizaw, S., Tesfay, Y., Mekasha, Y., Mekuriaw, Z., Gugsa, T., Ebro, A., ... \& Tegegne, A. (2016). Hormonal oestrus synchronization in four sheep breeds in Ethiopia: Impacts on genetic improvement and flock productivity.

https://cgspace.cgiar.org/bitstream/handle/10568/78 637/LIVES_wp_25.pdf?sequence=1

Gore, D. L. M. \& Lehloenya, K. C. (2020). ß-carotene supplementation increases progesterone concentration and glutathione peroxidase activity following alternative progesterone primed oestrus synchronization protocol in goats. American Journal of Animal and Veterinary Sciences. Vol. 15 (suppl.3), page $211-219$.

Grobbelaar, J. A. N., Sutherland, B., \& Molalakgotla, N. M. (2010). Egg production potentials of certain indigenous chicken breeds from South Africa. Animal Genetic Resources/Resources génétiques animales/Recursos genéticos animales, 46, 25-32.

Hasani, N., Ebrahimi, M., Ghasemi-Panahi, B., \& HosseinKhani, A. (2018). Evaluating reproductive performance of three oestrus synchronization protocols in Ghezel ewes. Theriogenology, 122, 9-13. https://www.sciencedirect.com/science/article/abs/pi i/S0093691X18304643
Hashemi, M., Safdarian, M., \& Kafi, M. (2006). Estrous response to synchronization of oestrus using different progesterone treatments outside the natural breeding season in ewes. Small Ruminant Research, 65(3), 279-283.

https://www.sciencedirect.com/science/article/abs/pi i/S0921448805003238

Kandiwa, E., Nguarambuka, U., Chitate, F., Samkange, A., Madzingira, O., Mbiri, P., ... \& Mushonga, B. (2020). Production performance of sheep and goat breeds at a farm in a semi-arid region of Namibia. Tropical Animal Health and Production, 52, 2621-2629. https://link.springer.com/content/pdf/10.1007/s1125 0-020-02283-w.pdf

Kasimanickam, R., Kasimanickam, V., \& Kappes, A. (2021). Timed artificial insemination strategies with or without short-term natural service and pregnancy success in beef heifers. Theriogenology, 166, 97-103. https://www.sciencedirect.com/science/article/abs/pi i/S0093691X21000820

Kenyon, P. R., Pinchbeck, G. L., Perkins, N. R., Morris, S. T., \& West, D. M. (2004). Identifying factors which maximise the lambing performance of hoggets: A cross sectional study. New Zealand Veterinary Journal, 52(6), 371-377. https://www.tandfonline.com/doi/abs/10.1080/0048 0169.2004.36454

Kridli, R. T., Abdullah, A. Y., \& Husein, M. Q. (2009). The effect of breed type and lactation status on reproductive performance in Awassi ewes. South African Journal of Animal Science, 39(sup-1), 15-18. https://journals.co.za/doi/abs/10.10520/EJC94705

Kunene, N. W., \& Fossey, A. (2006). A survey on livestock production in some traditional areas of Northern Kwazulu Natal in South Africa. Livestock Res Rural Dev, 18, 30-33. https://lrrd.cipav.org.co/lrrd18/8/kune18113.htm

Kunene, N. W., Nesamvuni, A. E., \& Nsahlai, I. V. (2009). Determination of prediction equations for estimating body weight of Zulu (Nguni) sheep. Small Ruminant Research, 84(1-3), 41-46. https://www.sciencedirect.com/science/article/abs/pi i/S0921448809000844

Kunene, N., Bezuidenhout, C. C., Nsahlai, I. V., \& Nesamvuni, A. E. (2011). A review of some characteristics, socio-economic aspects and utilization of Zulu sheep: Implications for conservation. Tropical Animal Health Production. Vol. 43, page 1075-1079. https://link.springer.com/article/10.1007/s11250011-9823-3

Lehloenya, K. C., Greyling, J. P. C., \& Schwalbach, L. M. J. (2005). Reproductive performance of South African indigenous goats following oestrous synchronization and AI. Small Ruminant Research, 57(2-3), 115-120. https://www.sciencedirect.com/science/article/abs/pii/S 0921448804002056 
Maqhashu, A. (2020). Characterization and evaluation of reproductive performance in Bapedi sheep breed. University of the Free State, Doctor of Philosophy, Thesis. https://scholar.ufs.ac.za/handle/11660/10427

Maqhashu, A., Mapholi, N. O., O’Neill, H. A., Nephawe, K. A., Ramukhithi, F. V., Sebei, J. P., Nxumalo, K. S. \& Nedambale, T. L. (2020). Assessment of genetic variation in Bapedi using microsatellite markers. South African Journal of Animal Sciences. Vol. 50 (suppl. 2), 318 - 324.

Martinez-Ros, P., \& Gonzalez-Bulnes, A. (2019). Efficiency of CIDR-based protocols including GnRH instead of eCG for oestrus synchronization in sheep. Animals, 9(4), 146. https://www.mdpi.com/20762615/9/4/146

Mavule, B. S., Muchenje, V., \& Kunene, N. W. (2013). Characterization of Zulu sheep production system: Implications for conservation and improvement. Scientific research and essays, 8(26), 1226-1238. https://academicjournals.org/journal/SRE/articleabstract/079710828332

Mavule, B. S., Sarti, F. M., Lasagna, E., \& Kunene, N. W. (2016). Morphological differentiation amongst Zulu sheep populations in KwaZulu-Natal, South Africa, as revealed by multivariate analysis. Small Ruminant Research, 140, 50-56.

https://www.sciencedirect.com/science/article/abs/pi i/S0921448816301419

Mbayahaga, J., Mandiki, S. N. M., Bister, J. L., \& Paquay, R. (1998). Body weight, oestrous and ovarian activity in local Burundian ewes and goats after parturition in the dry season. Animal Reproduction Science, 51(4), 289-300.

https://www.sciencedirect.com/science/article/abs/pi i/S0378432098000633

McManus, C. M., Faria, D. A., Lucci, C. M., Louvandini, H., Pereira, S. A., \& Paiva, S. R. (2020). Heat stress effects on sheep: Are hair sheep more heat resistant? Theriogenology, 155, 157-167.

https://www.sciencedirect.com/science/article/pii/S0 093691 X20303411

Mekuriaw, Z., Assefa, H., Tegegne, A., \& Muluneh, D. (2016). Oestrus response and fertility of Menz and crossbred ewes to single prostaglandin injection protocol. Tropical animal health and production, 48(1), 53-57.

https://link.springer.com/content/pdf/10.1007/s1125 0-015-0919-z.pdf

Molotsi, A. H., Dube, B., \& Cloete, S. W. P. (2020). The current status of indigenous ovine genetic resources in Southern Africa and future sustainable utilisation to improve livelihoods. Diversity, 12(1), 14. https://www.mdpi.com/1424-2818/12/1/14
Mpofu, T.J., Nephawe, K.A., Ginindza, M.M., Siwendu, N.A. \& Mtileni, B. 2021, Unpublished. Cow efficiency, relative-birth weight and subsequent preweaning growth performance of Nguni cattle.

Mukasa-Mugerwa, E., Anindo, D., Sovani, S., LahlouKassi, A., Tembely, S., Rege, J. E. O., \& Baker, R. L. (2002). Reproductive performance and productivity of Menz and Horro sheep lambing in the wet and dry seasons in the highlands of Ethiopia. Small Ruminant Research, 45(3), 261-271.

https://www.sciencedirect.com/science/article/abs/pi i/S0921448802001554

Ngcobo, J. N., Nedambale, T. L., Nephawe, K. A., Sawosz, E., \& Chwalibog, A. (2018). The future survival of African elephants: Implications for conservation. International Journal of Avian and Wildlife Biology, 3(5), 379-384.

https://curis.ku.dk/portal/files/204150621/The_futur e_survival_of_African_elephants_IJAWB_03_0012 3.pdf

Omontese, B. O., Rekwot, P. I., Ate, I. U., Ayo, J. O., Kawu, M. U., Rwuaan, J. S., ... \& Bello, A. A. (2016). An update on oestrus synchronization of goats in Nigeria. Asian Pacific Journal of Reproduction, 5(2), 96-101.

https://www.sciencedirect.com/science/article/pii/S2 305050016000117

Oyebade, F. A. O., Adewumi, O. O., \& James, I. J. (2012). Factors affecting birth and weaning weights in lambs of Yankasa, West African Dwarf breeds and their crosses. J. Agric. Sci. Env, 12(2), 89-95. https://core.ac.uk/download/pdf/233940485.pdf

Paulenz, H., Söderquist, L., Ådnøy, T., Fossen, O. H., \& Berg, K. A. (2003). Effect of milk-and TRIS-based extenders on the fertility of sheep inseminated vaginally once or twice with liquid semen. Theriogenology, 60(4), 759-766.

https://www.sciencedirect.com/science/article/abs/pi i/S0093691X03000487

Petrovic, M. P., Mus, L. I. C., Petrovic, D. R. V. C., \& Maksimovic, N. (2011). Influence of environmental factors on birth weight variability of indigenous Serbian breeds of sheep. African Journal of Biotechnology. Vol. 10 (suppl. 22), page 4673 - 4676.

https://www.ajol.info/index.php/ajb/article/view/94136

Qwabe, S. O. \& Van Marle-Köster, E. (2013). Genetic diversity and population structure of the endangered Namaqua Afrikaner sheep. Tropical Animal Health Production. Vol. 45, page 511 - 516.

Ramukhithi, F. V., Nedambale, T. L., Sutherland, B., Greyling, J. P. C., \& Lehloenya, K. C. (2012). Oestrous synchronization and pregnancy rate following artificial insemination (AI) in South African indigenous goats. Journal of Applied Animal Research, 40(4), 292-296.

https://www.tandfonline.com/doi/full/10.1080/0971 2119.2012.685280 
Robertson, S. M., \& Friend, M. A. (2019). Performance of sheep systems grazing perennial pastures. 2. Wool quality and lamb growth. Animal Production Science, 60(3), 406-413. https://www.publish.csiro.au/an/an18556

Safari, E., Fogarty, N. M., \& Gilmour, A. R. (2005). A review of genetic parameter estimates for wool, growth, meat and reproduction traits in sheep. Livestock Production Science, 92(3), 271-289. https://www.sciencedirect.com/science/article/abs/pi i/S0301622604001757

SAS, (1999). Statistical Analysis System User' Guide statistics. SAS Institute Inc. Cary NC 27513 USA.

Selepe, M. M., Ceccobelli, S., Lasagna, E., \& Kunene, N. W. (2018). Genetic structure of South African Nguni (Zulu) sheep populations reveals admixture with exotic breeds. PloS one, 13(4), e0196276. https://journals.plos.org/plosone/article?id=10.1371/ journal.pone.0196276

Shapiro, S. S., \& Wilk, M. B. (1965). An analysis of variance test for normality (complete samples). Biometrika, 52(3/4), 591-611. https://www.jstor.org/stable/2333709

Snedecor, G. W., \& Cochran, W. G. (1967). Statistical methods Iowa state university press.

Soma, P., Kotze, A., Grobler, J. P., \& Van Wyk, J. B. (2012). South African sheep breeds: Population genetic structure and conservation implications. Small Ruminant Research, 103(2-3), 112-119. https://www.sciencedirect.com/science/article/pii/S0 921448811003919
Uriol, M., Martinez-Ros, P., Rios, A., Encinas, T., \& Gonzalez-Bulnes, A. (2019). Onset of oestrus and periovulatory events in sheep exposed to 5 and 14 days of CIDR treatment with and without eCG. Reproduction in Domestic Animals, 54(11), 1489-1492.

https://onlinelibrary.wiley.com/doi/abs/10.1111/rda. 13537

Uslu, B. A., Tasal, I., Gulyuz, F., Sendag, S., Ucar, O., Goericke-Pesch, S., \& Wehrend, A. (2012). Effects of oestrus synchronization using melatonin and norgestomet implants followed by eCG injection upon reproductive traits of fat-tailed Morkaraman ewes during suckling, anoestrus season. Small Ruminant Research, 108(1-3), 102-106. https://www.sciencedirect.com/science/article/abs/pi i/S0921448812002611

Zeleke, M., Greyling, J. P. C., Schwalbach, L. M. J., Muller, T., \& Erasmus, J. A. (2005). Effect of progestagen and PMSG on oestrous synchronization and fertility in Dorper ewes during the transition period. Small ruminant research, 56(1-3), 47-53. https://www.sciencedirect.com/science/article/abs/pi i/S0921448804000057 